\title{
Changes in the Catalytic Activities of Proteoglycan-Degrading Lysosomal Enzymes in Parenchymal and Non-Parenchymal Liver Cells and in Serum 'During the Development of Experimental Liver Fibrosis
}

\author{
By W. Weber, T. Kehrer, A. M. Gressner, H. W. Stuhlsatz and H. Greiling \\ Department of Clinical Chemistry and Pathobiochemistry \\ Medical Faculty of the University (RWTH) Aachen
}

(Received September 29/December 3,1982)

\begin{abstract}
Summary: The catalytic activities of 4 glycosidases (hyaluronate-4-glycanohydrolase (EC 3.2.1.35), $\beta$-Nacetyl- $D$-glucosaminidase (EC 3.2.1.30), $\beta$-glucuronidase (EC 3.2.1.31), $\alpha$ - $L$-iduronidase (EC 3.2.1.76)), of the arylsulphatases $A$ and $B$ (EC 3.1.6.1) and of the protease cathepsin D (EC 3.4.23.5) were measured in extracts from hepatocytes and non-parenchymal cells and in serum during the development of thioacetamideinduced rat liver fibrosis (22 weeks). In non-parenchymal liver cells the catalytic activities of $\beta$ - $\mathrm{N}$-acetyl- $D$ glucosaminidase, $\beta$-glucuronidase, $\alpha$ - $L$-iduronidase and cathepsin $D$ were increased significantly during chronic liver damage, but that of hyaluronate-4-glycanohydrolase was reduced by 40 to $65 \%$ during the period of application of thioacetamide. The catalytic activities of the arylsulphatases were lowered by $65 \%$ compared to control values in the 12th week but with advancing liver damage the catalytic activities returned to nearly normal values. Parenchymal cells of rats, which had been liver-damaged for 6 months, contained strongly elevated activities of $\beta$-glucuronidase, $\beta$ - $\mathrm{N}$-acetyl- $D$-glucosaminidase, arylsulphatases $\mathrm{A}$ and $\mathrm{B}$, and cathepsin $D$ but only slightly increased activities of hyaluronate-4-glycanohydrolase and $\alpha$ - $L$-iduronidase, respectively.

In the serum of liver-damaged rats the activity of $\alpha-L$-iduronidase was strongly elevated, while that of $N$ acetyl- $\beta$ - $D$-glucosaminidase was only slightly increased. The activities of $\beta$-glucuronidase and of arylsulphatases A and B were decreased during the whole period of treatment. The catalytic functions of hyaluronate-4glycanohydrolase and of cathepsin D, respectively, were decreased initially, but both enzyme activities were elevated during the more advanced stages of long term thioacetamide treatment.
\end{abstract}

Aktivitätsänderungen Proteoglykan-abbauender, lysosomaler Enzyme in Parenchym- und Nicht-Parenchymzellen der Leber sowie im Serum während der Entwicklung einer experimentellen Leberfibrose

Zusammenfassung: Die katalytischen Aktivitäten von vier Glykosidasen (Hyaluronat-4-glykanohydrolase (EC 3.2.1.35), $\beta$-N-Acetyl-D-glucosaminidase (EC 3.2.1.30), $\beta$-Glucuronidase (EC 3.2.1.31), $\alpha-L$ Iduronidase (EC 3.2.1.76)) sowie zweier Sulfatasen (Arylsulfatase A und B) (EC 3.1.6.1) und einer Protease (Kathepsin D) (EC 3.4.23.5) wurden in den löslichen Extrakten von Hepatocyten und Nicht-Parenchymzellen der Leber und im Serum im Verlaufe einer Thioacetamid-induzierten Leberfibrose (22 Wochen) bestimmt. In Nicht-Parenchymzellen sind die katalytischen Aktivitäten der $\beta$-N-Acetyl- $D$-glucosaminidase, $\beta$-Glucuronidase, $\alpha$ - $L$-Iduronidase und Kathepsin $D$ bei chronischer Leberschädigung signifikant erhöht, wohingegen die katalytische Aktivität der Hyaluronat-4-glykanohydrolase im gesamten Untersuchungszeitraum um 40 bis $65 \%$ vermindert ist. Die katalytischen Aktivitäten der Arylsulfatasen A und B waren in der 12. Woche der Schädigung um 65\% erniedrigt (verglichen mit den Kontrollen), mit fortschreitender Leberschädigung wurden jedoch wieder Normalwerte erreicht. Parenchymzellen von Ratten, die 6 Monate mit Thioacetamid geschädigt waren, zeigten stark erhöhte katalytische Aktivitäten der $\beta$-Glucuronidase, der $\beta$-N-Acetyl-D-glucosaminidase, der Arylsulfatasen A und B, des Kathepsin D, aber nur gering erhöhte katalytische Aktivitäten der Hyaluronat-4-glykanohydrolase und der $\alpha$ - $L$-Iduronidase. 
Im Serum geschädigter Ratten wurden stark erhöhte katalytische Aktivitäten der $\alpha$ - $L$-Iduronidase festgestellt, wohingegen die der $\beta$-N-Acetyl- $D$-glucosaminidase nur leicht erhöht war. Die katalytischen Aktivitäten der $\beta$-Glucuronidase und der Arylsulfatasen A und B waren während des gesamten Behandlungszeitraums vermindert. Die katalytischen Funktionen der Hyaluronat-4-glykanohydrolase und des Kathepsin D waren initial erniedrigt, in fortgeschrittenen Stadien der langzeitigen Thioacetamid-Behandlung wiesen beide Enzyme deutliche Aktivitätssteigerungen auf.

i

\section{Introduction}

Proteoglycans as well as glycosaminoglycans play an important role in pathobiochemical changes of many liver diseases especially in the course of the fibrotic transformation of the organ $(1,2)$. According to several authors $(3-8)$, the proteoglycans and glycosaminoglycans of fibrotic human liver and of experimental fibrotic animal liver show significant increases, molecular changes and topohistological distortions. These changes occur chiefly in the hyaluronate, chondroitin sulphate and dermatan sulphate fractions. The extensive accumulation of intercellular glycosaminoglycans in cirrhotic and fibrotic liver tissue is mainly ascribed to active mechanisms like enhanced synthesis (9-12), but the knowledge of contributory mechanisms is scanty. Passive processes like the deposition of extrahepatically synthesized proteoglycans in the liver $(13,14)$ and/or inhibition of hepatic glycosaminoglycan degradation by reduced lysosomal enzyme activities in chronically injured liver tissue are possible, but as yet experimentally unproven. Since both hepatocytes and non-parenchymal liver cells (mainly Kupffer cells and endothelial cells) contain a whole set of glycosaminoglycan degrading lysosomal enzymes $(15-21)$ the activities of several important glycosidases, (hyaluronate-4-glycanohydrolase, $\beta$ - $D$-glucuronidase, $\beta$-Nacetyl- $D$-glucosaminidase, $\alpha-L$-iduronidase), of two sulphatases (arylsulphatases A and B) and of one protease (cathepsin D) were studied in both cell types, and, additionally, in the serum of normal and chronically injured rats. These experiments were performed to elucidate the role of the lysosomal glycosaminoglycan-degrading enzyme system in the development of thioacetamide-induced liver fibrosis.

\section{Materials and Methods}

Chemicals

Pronase was obtained from Calbiochem-Behring, La Jolla, U.S.A.; collagenase (type I), triton $X-100$ and the enzyme substrates $p$-nitrophenyl- $\beta$ - $D$-glucuronide, $p$-nitrophenyl- $N$-acetyl$\beta$ - $D$-glucosaminide, $p$-nitrocatechol-sulphate, hyaluronic acid (grade I) and bovine haemoglobin (type II) were from Sigma Chemical Comp. Munich, FRG; Hank's balanced salt solution and Dulbeccos modification of Eagles medium were purchased from Flow Laboratories GmbH, Bonnn, FRG; thioacetamide was from E. Merck AG, Darmstadt; phenyl- $\alpha$ - $L$-iduronide was a generous gift from Dr. B. Weissmann of the Uñiversity of Illinois, U.S.A. All other chemicals were p.a. quality from E. Merćk AG, Darmstadt.

\section{Treatment of the animals}

Male Sprague-Dawley rats (Lippische Versuchstierzucht, Extertal, FRG), weighing 200-250 g, were used. The rats were fed a standard rat diet and received water ad libitum. Half of the rats received continuously thioacetamide in the drinking water at a concentration of $0.3 \mathrm{~g} /$ during the whole experimental period of 22 weeks. The other half of the rats received normal water without the toxic agent (control rats).

After various time periods, experimental and control rats were anaesthetized with Nembutal (Serva, Heidelberg), $1-2 \mathrm{ml}$ of blood was aspirated from $\mathrm{V}$. cava inferior and the liver was cannulated via the portal vein to prepare parenchymal and non-parenchymal cells as described below.

\section{Preparation of non-parenchymal cells}

The liver was first perfused in a non-circulating manner (flow rate $30 \mathrm{ml} / \mathrm{min}$ ) via the portal vein for $3-5 \mathrm{~min}$ at $37^{\circ} \mathrm{C}$ with oxygenated $\mathrm{Ca}^{2+}$-free Hank's balanced salt solution, containing 0.03 mol/ of $\mathrm{NaHCO}_{3}$. Hank's balanced salt solution $(10 \mathrm{ml})$ containing $5 \mathrm{mmol} / 1 \mathrm{Ca}^{2+}$ and $2 \mathrm{~g} / \mathrm{l}$ pronase was then injected (22). The liver was removed, transfered into a Petri dish with buffer and carefully disintegrated at room temperature. After oxygenation with $\mathrm{O}_{2} / \mathrm{CO}_{2}$ (fractions $0.95 / 0.05$ ) for $2 \mathrm{~min}$, the liver fragments were incubated under constant agitation for $1 \mathrm{~h}$ at $37^{\circ} \mathrm{C}$ in Hank's balanced salt solution containing $\mathrm{Ca}^{2+}$ and pronase. Thereafter, the tissue-cell suspension was filtered through sterile gauze, centrifuged for $5 \mathrm{~min}$ at $610 \mathrm{~g}$ and resuspended in cold washing buffer according to Seglen (23). Non-parenchymal cells were purified by washing, and the final cell preparation was suspended in a small volume of Dulbecco's modification of Eagles medium. The viability of the cells checked by the trypan blue exclusion test was around $92 \%$, the contamination with parenchymal cells was less than $1 \%$.

\section{Preparation of liver parenchymal cells}

Hepatocytes were prepared by a two-step perfusion procedure essentially according to Seglen $(23-25)$. The organ was initially perfused in situ for 10 min in a non circulating way via the portal vein with $\mathrm{Ca}^{2+}$-free oxygenated Hank's balanced salt solution at a flow rate of $30 \mathrm{ml} / \mathrm{min}$. Thereafter, recirculating perfusion was performed for a further $10 \mathrm{~min}$ at a flow rate of $50 \mathrm{ml} / \mathrm{min}$ with Hank's balanced salt solution containing $0.5 \mathrm{~g} / \mathrm{l}$ collagenase and $5 \mathrm{mmol} / 1 \mathrm{Ca}^{2+}$. The medium was continuously gassed with $\mathrm{O}_{2} /$ $\mathrm{CO}_{2}$ (fractions 0:95/0.05). After finishing the perfusion, the liver capsule was carefully removed and the tissue dissected. The resulting initial cell suspension was filtered through sterile gauze and then through nylon filters of different pore size (250, $100 \mu \mathrm{m})$. The filtered cells were centrifuged for $2 \mathrm{~min}$ at $36 \mathrm{~g}$ and $4^{\circ} \mathrm{C}$, gently resuspended and washed two times by centrifugation $\left(2 \mathrm{~min}, 17 \mathrm{~g}, 4^{\circ} \mathrm{C}\right)$. The final cell sediment was resuspended in Dulbecco's modification of Eagles medium. More than $90 \%$ of hepatocytes excluded trypan blue, the contamination with nonparenchymal cells was about $1-2 \%$. . 


\section{Homogenization of cells}

Ice-cold Triton-X-100 (1 g $/)$ solution was added to the purified parenchymal and non-parenchymal cells which had been adjusted to a cell concentration of $1 \times 10^{10} \Lambda$. After incubation for $25 \mathrm{~min}$ at $4^{\circ} \mathrm{C}$, the suspension was homogenized at $0-4^{\circ} \mathrm{C}$ in a Potter-Elvehjem homogenizer. Cell debris were separated from the homogenate by centrifugation $\left(1000 \mathrm{~g}, 5 \mathrm{~min}, 4^{\circ} \mathrm{C}\right)$. The supernatant was diluted with ice-cold distilled water.

Protein was determined in the cell extract according to the method of Bradford (26) using bovine $\gamma$-globulin as a standard (Bio Rad Laboratories, Munich, FRG).

\section{Collection of serum}

Blood (1-2 $\mathrm{ml})$ was aspirated from the $\mathrm{V}$. cava inferior prior to the perfusion of the liver. After complete coagulation blood was centrifuged and the serum diluted with cold $0.15 \mathrm{~mol} / \mathrm{NaCl}$.

Enzyme catalytic activities were determined immediately after obtaining the sera and the cell extracts, respectively.

Determination of lysosomal enzyme catalytic activities

$\beta$-N-acetyl- $D$-glucosamidase (EC 3.2.1.30) was determined with $p$-nitrophenyl- $\mathrm{N}$-acetyl- $\beta$ - $D$-glucosaminide as substrate in 0.1 mol/ 1 sodium citrate buffer, $\mathrm{pH} 4.3$ (27); $\beta$-glucuronidase (EC 3.2.1.31) was determined with $p$-nitrophenyl- $\beta-D$-glucuronide as substrate according to the method described by Hall (28) with slight modifications. Arylsulphatase A and arylsulphatase B (EC 3.1.6.1) were determined spectrophotometrically with 2-hydroxy5 -nitrophenylsulphate as substrate in $0.25 \mathrm{~mol} / 1$ sodium acetate buffer, $\mathrm{pH} 5.0$ and $\mathrm{pH} 6.0$, respectively $(27,29)$. The catalytic activity of cathepsin D (EC 3.4.23.5) was measured in $0.25 \mathrm{~mol} / \mathrm{h}$ sodium formate buffer, pH3.3 with denatured bovine haemoglobin as substrate (27). The concentration of the liberated peptides was determined by the Lowry procedure (30).

Hyaluronate-4-glycanohydrolase (EC 3.2.1.35) was assayed with hyaluronic acid as substrate in $0.25 \mathrm{~mol} / \mathrm{l}$ sodium formate buffer, pH 3.8 (27). The activity of $\alpha$ - $L$-iduronidase (EC 3.2.1.76) was measured with phenyliduronide as substrate according to the method described by Hall (28) with a minor modification.

The activities of the enzymes are refered to the concentration of protein in the cell extracts. Under all assay conditions enzyme activities were linear with time of incubation and concentration of cell extracts and serum, respectively.

\section{Results}

Lysosomal enzyme catalytic activities in rat liver nonparenchymal cells during thioacetamide-induced liver fibrosis

The continuous application of thioacetamide to rats generates liver fibrosis. This process is accompanied by an elevation of most of the studied lysosomal enzyme catalytic activities in non-parenchymal liver cells. The enzymes $\beta$-glucuronidase and cathepsin $D$ are enhanced 2.6 and 1.9 fold, respectively, 3 weeks after initiation of liver damage (fig. $1 b, 2 c$ ). While the catalytic activities of these enzymes decrease in the further course of liver damage, the glycosidases $\alpha$ - $L$-iduronidase and $\beta-\mathrm{N}$-acetyl- $D$-glucosaminidase increase gradually, reaching maximum activities ( 2
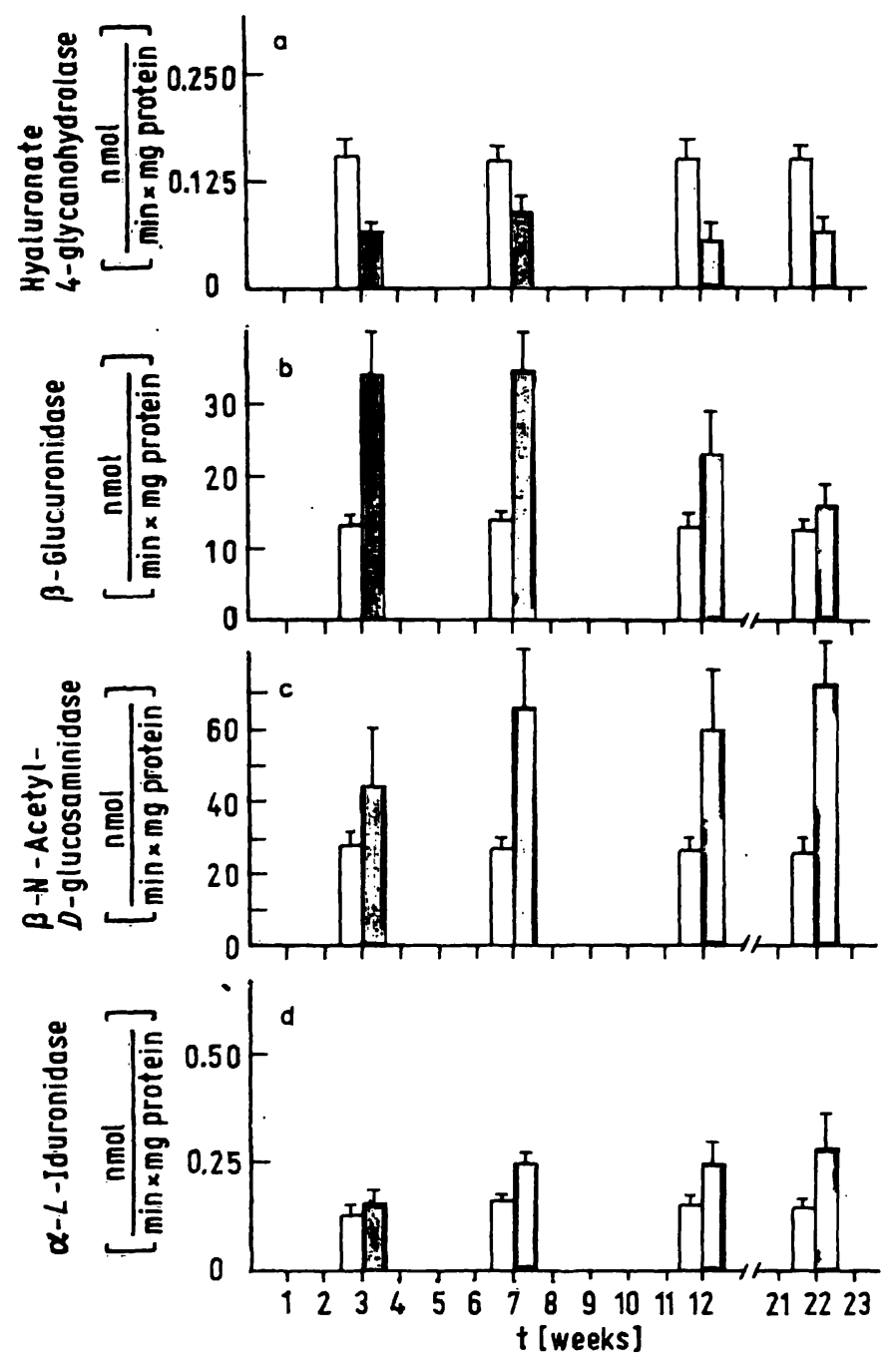

Fig. 1. Specific catalytic activities of 4 lysosomal glycosidases in rat liver non-parenchymal cells during the development of thioacetamide-induced liver fibrosis: hyaluronate-4-glycanohydrolase (a), $\beta$-glucuronidase (b), $\beta$-N-acetyl- $D$ glucosaminidase (c) and $\alpha$ - $\dot{L}$-iduronidase (d).

Open columns represent enzyme catalytic activities in nonparenchymal cells of control rats, black columns represent those in non-parenchymal cells from treated rats. Each value is the mean $\pm S$. D. of preparations from 6 different rats. For further details see materials and methods.

and 2.8 fold, respectively, above normal) after 22 weeks (fig. 1). The catalytic activity of arylsulphatase B was elevated 1.7 fold in the third week, whereas that of arylsulphatase A remained in the normal range at this time point. In the further course of chronic liver damage both arylsulphatases decrease in catalytic activity (fig. $2 a, b$ ). The activity profile of the lysosomal hyaluronate-4-glycanohydrolase was found to be quite different from that of the other enzymes (fig. 1a); during the whole period of thioacetamide application the catalytic activity was significantly reduced, in general between 30 and $60 \%$ of that assayed in non-parenchymal cells from untreated rats. 

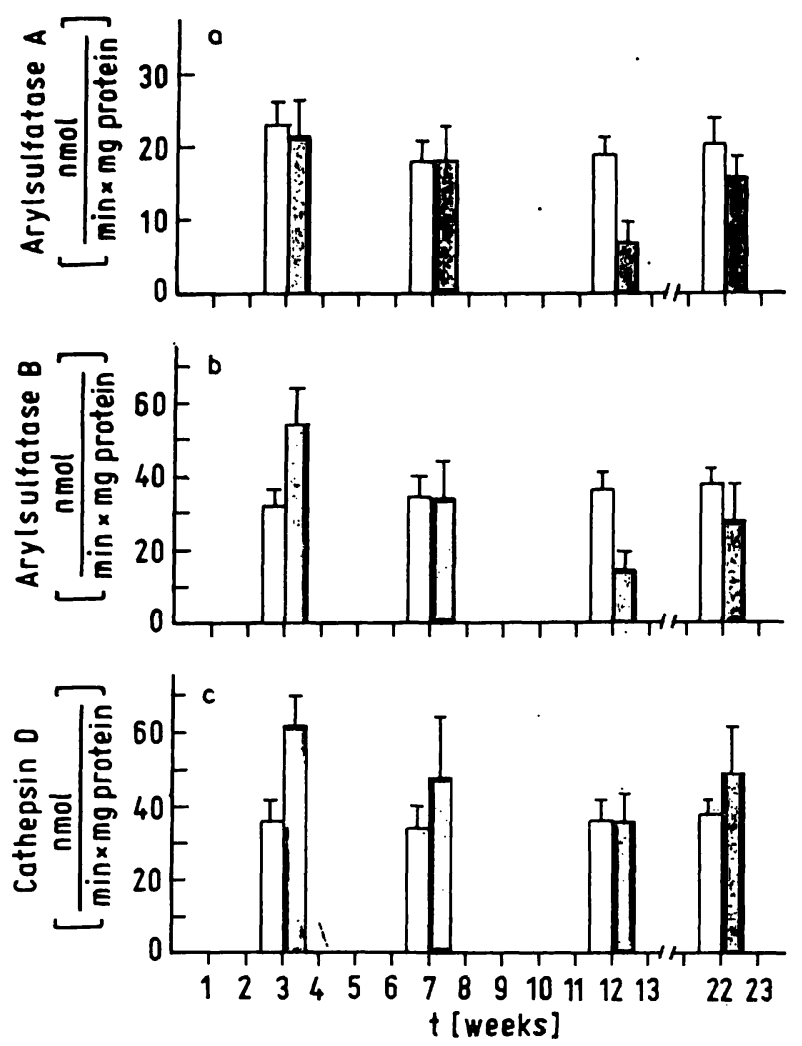

Fig. 2. Specific catalytic activities of lysosomal arylsulphatases $\mathbf{A}$ (a) and B (b) and cathepsin D (c) in rat liver non-parenchymal cells during thioacetamide-induced liver fibrosis.

Open columns represent enzyme catalytic activities in non-parenchymal cells of control rats, black columns represent those in cells from treated rats. Each value is the mean $\pm S$. D. of preparations from 6 different rats. For further details see materials and methods.

Lysosomal enzyme catalytic activities in serum of rats, during induced liver fibrosis

Long term thioacetamide-induced liver injury is accompanied by reduced catalytic activities of most of the lysosomal enzymes studied in serum (fig. 3,4 ). The catalytic activities of $\beta$-glucuronidase and arylsulphatase $A$ were found to be diminished throughout the whole period of liver injury (fig. 3b, 4a). The catalytic activities of four of the enzymes studied, i. e. hyaluronate-4-glycanohydrolase, $\beta-\mathrm{N}$-acetyl- $D$ glucosaminidase, arylsulphatase $B$ and cathepsin $D$ showed a tendency to increase during long time liver damage (fig. 3a, c, fig. 4b, c). The catalytic activity of cathepsin D in serum was 3.5 fold above normal in the 22 th week. The enzyme profile of $\alpha-L$-iduronidase was quite different from that of the other enzymes; over the whole experimental period the catalytic activity was greatly increased ( 3 fold above normal) reaching a maximum at the 7 th week (fig. 3d).
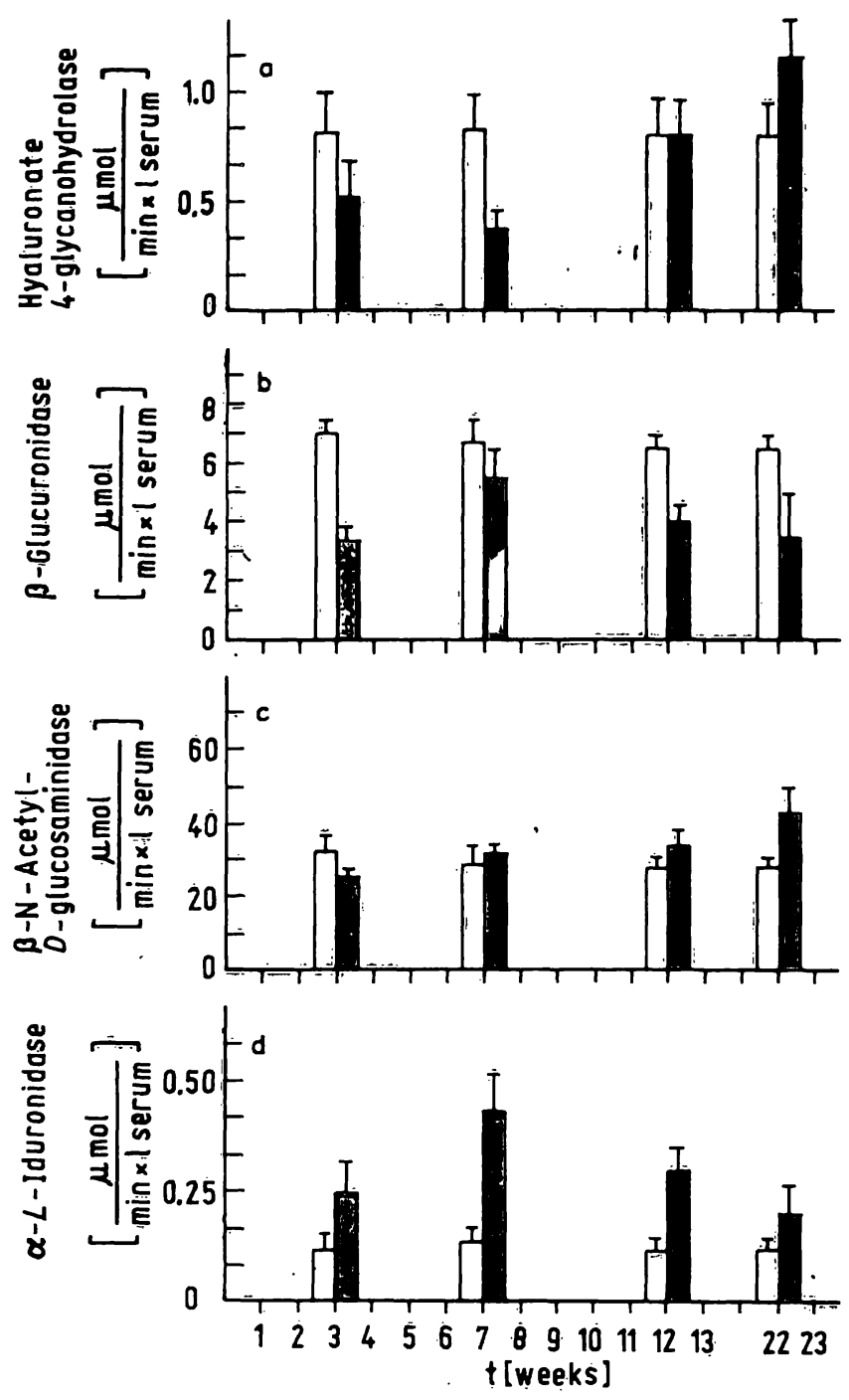

Fig. 3. Catalytic activity concentrations of 4 glycosidases in rat serum over the whole thioacetamide application period: hyaluronate-4-glycanohydrolase (a), $\beta$-glucuronidase (b), $\beta$ - $\mathrm{N}$-açetyl $=D$-ğlucosaminidase (c) and $\alpha$ - $L$-iduronidase (d).

Open columns represent the enzyme catalytic activities in the sera of control rats, black colümns repiresent those in the sera of treated rats. Each value is the mean \pm S.D. from 6 different rats. For further details see materials and methods.

\section{Lysosomal enzyme catalytic activities in hepatocytes from long term liver damaged rats}

As shown in figure 5 the catalytic activities of the glycosidases, arylsulfatases A and B and of cathepsin $D$ are increased in hepatocytes from rats which were liver-damaged for 6 months with thioacetamide. With the exceptions of hyaluronate-4-glycanohydrolase and $\alpha$ - $L$-iduronidase, which were only slightly elevated, other enzyme catalytic activities were in:creased about 2 -fold in hepatocytes from long tèrm damaged liver (fig. 5). 

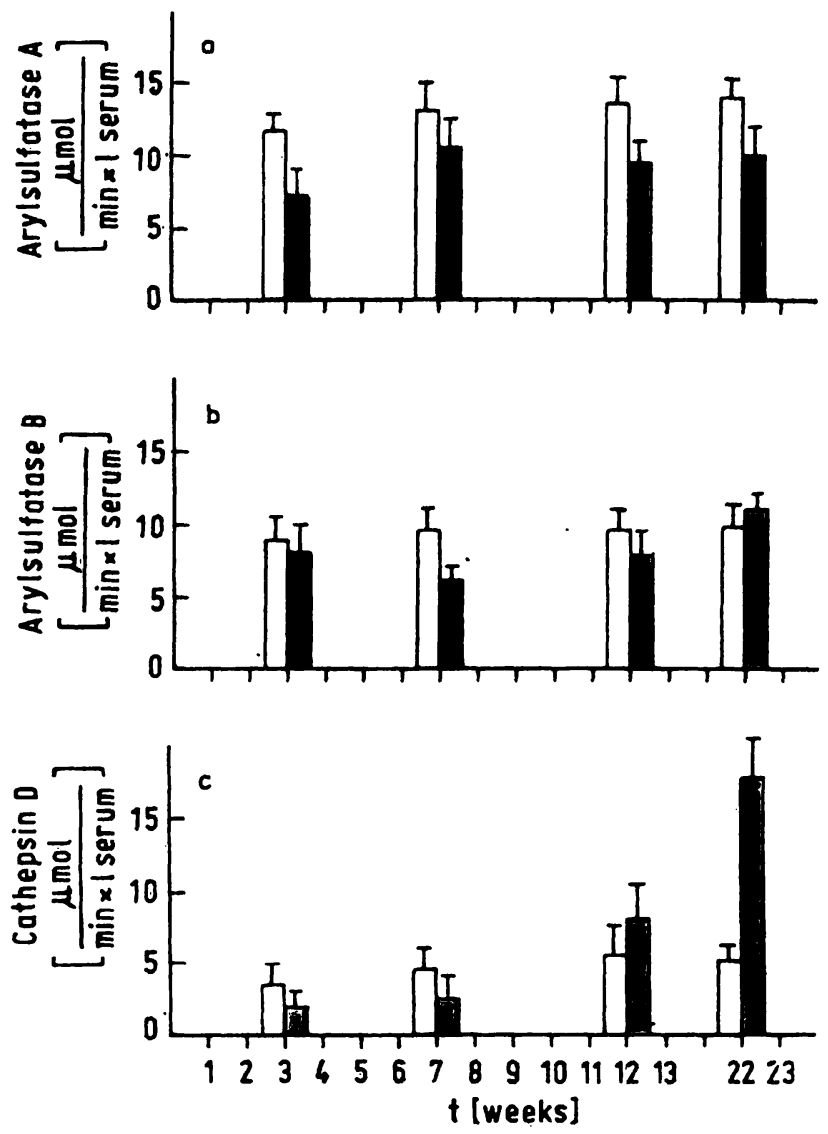

Fig. 4. Catalytic activity concentrations of arylsulfatase $A$ (a) and $B$ (b) and of cathepsin D (c) in rat serum over the whole thioacetamide application period.

Open columns represent the enzyme catalytic activity concentrations in serum of control rats, black columns represent those in serum of treated rats. Each value is the mean \pm S. D. of 6 preparations. For further details see materials and methods.

\section{Discussion}

The experiments described here demonstrate an increase in the catalytic activities of $\beta$-glucuronidase, $\beta$ - $\mathrm{N}$-acetyl- $D$-glucosaminidase, $\quad \alpha$ - $L$-iduronidase and cathepsin $D$ in non-parenchymal liver cells during the development of experimental liver fibrosis. The same enzymes were also more catalytically active in extracts from hepatocytes of chronically damaged liver ( 6 months) than in those, isolated from normal liver. It is of great interest that the catalytic activity of hyaluronate-4-glycanohydrolase was found to be significantly diminished in non-parenchymal cells over the whole experimental period. In hepatocytes, the catalytic activity of this enzyme was only slightly stimulated. A similar decrease of hyaluronate-4-glycanohydrolase catalytic activity in total liver was described by Hutterer (31) in the irreversible stage of experimental fibrosis, but in the initial stage (reversible fibrosis) an increase of catalytic activity was found. The data are at variance with those of Nakamura et al., who reported an increase of this enzyme catalytic activity in $\mathrm{CCl}_{4}$-damaged liver (32). The lysosomal hyaluronate-4-glycanohydrolase degrades hyaluronate and, at a slower rate, chondroitin-4-sulphate, chondroitin-6-sulphate and dermatan sulphate (33). The reduced catalytic activity of this endoglycosidase might be responsible for the accumulation of the respective types of glycosaminoglycans, in particular of chondroitin sulphate, dermatan sulphate and hyaluronate $(4,8)$ in fibrotic liver. The increase in the catalytic activities of the exoglycosidase obviously cannot compensate for a
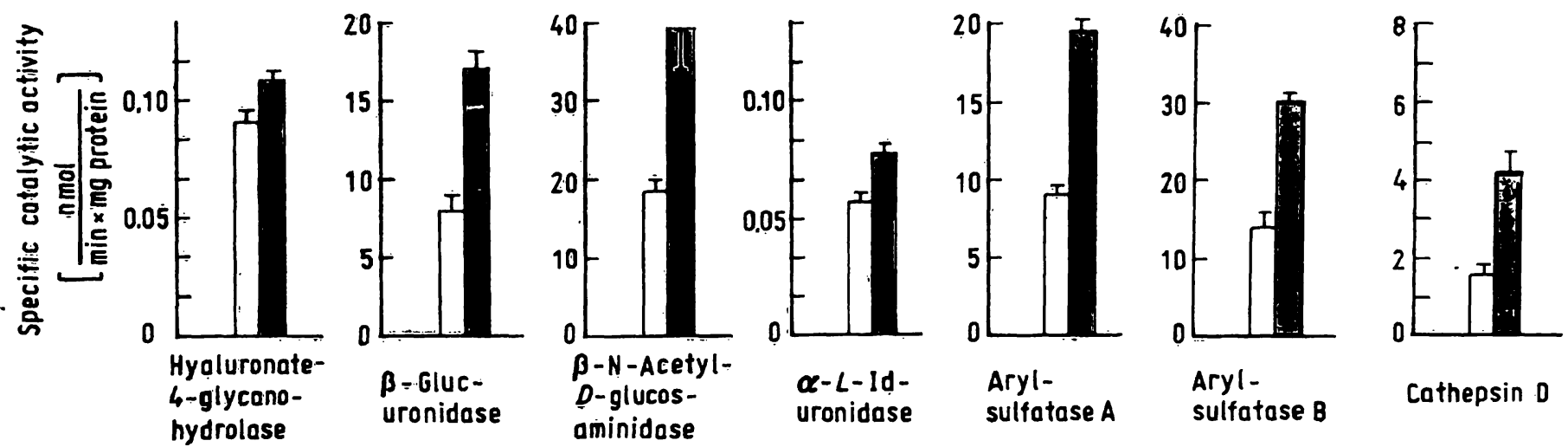

Fig. 5. Specific catalytic activities of lysosomal enzymes in parenchymal liver cells of rats injured for 6 months with thioacetamide.

Open columns represent specific catalytic activities of parenchymal cells isolated from control rats, black columns those in hepatocytes from treated rats. Each value is the mean \pm S. D. for preparations from 6 different rats. For further details see materials and methods. 
possible inhibition of the degradation of glycosaminoglycans due to a decrease of endoglycosidically active hyaluronate-4-glycanohydrolase; the former enzymes act mainly on oligosaccharides $(34,35)$, and in the case of chondroitin sulphate and dermatan sulphate they act on the desulphated oligosaccharides at the non-reducing terminal (36). The important role of hyaluronate-4-glycanohydrolase in the catabolism of liver glycosaminoglycans is suggested by Constantopoulos et al. (37) from studies with the trypanocidal drug suramin. In the presence of this drug the strong inhibition of the enzyme is accompanied by an increase in the total glycosaminoglycan concentration in rat liver tissue.

Our results describe reduced catalytic activities of both arylsulphatases in advanced stages of the development of liver fibrosis. The deficiency of the arylsulphatase $\mathrm{B}$, which cleaves the C4-sulfate groups from glycosaminoglycans might also be related to the accumulation of chondroitin-4-sulphate and dermatan sulphate in liver parenchyma, as found in the Maroteaux-Lamy syndrome $(38,39)$, where the genetically caused lack of arylsulphatase B results in tissue storage and urinary excretion of chondroitin sulphate and dermatan sulphate. According to this pathologic condition the reduced catalytic activity of arylsulphatase $B$, as it is demonstrated here, could impair the degradation of glycosaminoglycans.
With the exception of the significant increase in catalytic activity of $\alpha-L$-iduronidase and cathepsin $D$ in terminal stages of chronic injury the catalytic activity of the other lysosomal enzymes were found to be decreased or only slightly stimulated in the sera of treated rats. A moderate increase of $\beta-\mathrm{N}$-acetyl- $D$ glucosaminidase catalytic activity $(32,40)$ and hyaluronate-4-glycanohydrolase catalytic activity (32) in sera of rats with chronic hepatic damage was observed previously, but the profile of other glycosaminoglycan-degrading lysosomal enzymes of liverinjured rats has not been reported. Although the pathobiochemical mechanism of our finding is not yet clear, disturbances in the balanced transport equilibrium of lysosomal enzymes between lysosomes and the extracellular space might be responsible for the increase of catalytic activities in the cells and the simultaneous decrease in serum during initial stages of injury (41). The pattern of lysosomal enzyme catalytic activity in the serum of chronically liver-damaged rats does not suggest any enzyme as a biochemical marker of experimental liver fibrosis, since the changes were often only moderate and strongly dependent on the time point of chronic liver damage.

\section{Acknowiledgement}

We gratefully acknowledge the expert technical assistance of Mr. Bert Delvoux in the preparation of cells.

\section{References}

1. Gerlach, U., Pott, G., Rautenberg, J. \& Voss, B. (eds.) (1982) Connective Tissue of the Normal and Fibrotic Human Liver, Thieme, Stuttgart + New York.

2. Gressner, A. M. (1980) Med. Welt 31, 11-16.

3. Delbrück, A. (1968) J. Clin. Chem. Clin. Biochem. 6, 460466.

4. Becker, K. (1969) Z. Ges. Exp. Med. 151, 1-9.

5. Koizumi, T., Nakamura, N. \& Abe, H. (1967) Biochim. Biophys. Acta $148,749-756$.

6. Stuhlsatz, H. W., Vierhaus, S., Gressner, A. M. \& Greiling, .H. (1982) Falck Symp. 34, 135-136.

7. Galambos, J. T. \& Shapira, R. (1973) J. Clin. Invest 5̦2, 2952-2962.

8. Kojima, J., Nakamura, N., Kanatani, N. \& Ohmori, K. (1975) Cancer Res. 35, 542-547.

9. Gressner, A. M., Pazén, H. \& Greiling, H. (1977) Experientia (Basel) 33, 1290-1292.

10. Gressner, A. M., Pazen, H. \& Greiling, H. (1977) HoppeSeyler's Z. Physiol. Chem. 358, 825-833.

11. Gressner, A. M., Heinrigs, S. \& Grouls, P. (1982) J. Clin. Chem. Clin. Biochem. 20, 15-24.

12. Gressner, A. M. \& Grouls, P. (1982) Digestion 23, 259-264.

13. Oldberg, A., Höök, M., Obring, B., Pertoft, H. \& Rubin, K. (1977) Biochem. J. 164, 75-81.

14. Gressner, A. M., Köster, W., Van de Leur, E. \& Bruns, D. (1978) Fresenius Z. Anal. Chem. 290, 150-151.

15. Knook, D. L. \& Sleyster, Ch. E. (1976) Mech. Ageing Development $5,389-397$.
16. Munthe-Kaas, A. C., Berg, T. \& Seljelid, R. (1976) Exp. Cell Res. 99, 146-154.

17. Berg, T. \& Munthe-Kaas, A. C. (1977) Exp. Cell Res. 109, $119-125$.

18. Lentz, P. E. \& Di Luzio, N. R. (1971) Exp. Cell Res. 67, 1726.

19. Van Berkel, T. J. C., Kruijt, J. K. \& Koster, J. F. (1975) Eur. J. Biochem. 58, 145-152.

20. Knook, D. L., Blansjaar, N. \& Sleyster, E. Ch. (1977) Exp. Cell Res. 109, 317-329.

21. Knook, D. L. \& Sleyster, E. Ch. (1980) Biochem. Biophys. Res. Commun. 96, 250-257.

22. Mills, D. M. \& Zucker-Franklin, D. (1969) Am. J. Pathol. $54,147-166$.

23. Seglen, P. O. (1976) In: "Methods of cell biology", Vol. 8, (Prescott D. M., ed.), Acad. Press N.Y., San Francisco, London pp. 29-83.

24. Seglen, P. O. (1973) Exp. Cell Res. 82, 391-398.

25. Seglen, P. O. (1972) Exp. Cell Res. 74, 450-454.

26. Bradford, M. M. (1976) Añal. Biochem. 72, 248-254.

27. Barrett, A. J. \& Heath, M. F. (1977) In: "Lysosomes", a Laboratory handbook (J. T. Dingle ed.), North Holland Publ. Company, Amsterdam, N.Y., Oxford, pp. 19-145.

28. Hall, C. W., Liebaers, J., DiNatale, P. \& Neufeld, E. F. (1978) Methods Enz̈ymol. 50, 439-456.

29. Baum, H., Dodgson, K. S. \& Spencer, B. (1959) Clin. Chim.. Acta $4,453-455$. 
30. Lowry, O. H., Rosebrough, N. J., Farr, A. L. \& Randall, R. J. (1951) J. Biol. Chem. 193, 265-275.

31. Hutterer, F. (1966) Biochim. Biophys. Acta 115, 312-319.

32. Nakamura, N., Iwabori, N. \& Koizumi, T. (1970) Clin. Chim. Acta 27, 47-52.

33. Meyer, K. (1971) In: "The Enzymes" (Boyer, P. D., ed.), Vol. V, pp. 307-320 Academic Press, New York, London.

34. Kennedy, J. F. (1979) In: "Proteoglycans - Biological and Chemical aspects in human life", pp. 195-223, Elsevier scientific pub. comp. Amsterdam, Oxford, New York.

35. Roden, L. (1980) In: "The Biochemistry of Glycoproteins and Proteoglycans (Lennarz, W. J.; ed.) pp. 267-371, Plenum press New York, London.
36. Keiser, H. (1980) In: "Handbook of inflammation", Vol. 2 (Glynn, L. E., Houck, J. C. \& Weissmann, G. Eds.), pp. 447, .431-495, Elsevier, North-Holland Biomed. Press, Amsterdam, New York, Oxford.

37. Constantopoulos, G., Rees, S., Cragg, B. G. Barranger, J. A. \& Brady, R. O. (1980) Proc. Natl. Acad. Sci. U.S.A., 77, 3700-3704.

38. Fluharty, A. L., Stevens, R. L., Sanders, D. L. \& Kihara, H. (1974) Biochem, Biophys. Res. Commun. 59, 455-461.

39. O'Brien, J. S. (1975) Clin. Gen. 8, 303-311.

40. Koizumi, T., Suematsu, T., Iwabori, N. \& Abe Hiroshi (1968) Biochim. Biophys. Acta 151, 628-636.

41. Fiszer-Szafarz, B. \& Szafarz, D. (1973) Cancer Res. 33, 1104-1108.

Dr. rer. nat. W. Weber

Prof. Dr. med. A. M. Gressner

Abteilung Klinische Chemie und Pathobiochemie Klinisch-Chemisches Zentrallaboratorium der Medizinischen Fakultät der RWTH Aachen Goethestr. 27-29

D-5100 Aachen 
" 